\title{
MISCELLANEOUS COMMUNICATIONS
}

\author{
PUBLICATIONS RECEIVED
}

BAILey, H. W., Dvārā matīnām, BSOAS, 20 (1957), pp. 41--59 [I: Old Indian āyú-; II: Avestan aganyā-; III: Old Indian prapharvit-; IV: Iranian angu-; V; Old Indian angoșin-; VI: Old Indian durósa-; VII: Khotanese șara; VIII: Khotanese pau].

- A Problem of the Indo-Iranian Vocabulary, Rocznik Orientalistyczny, 21 (1957),

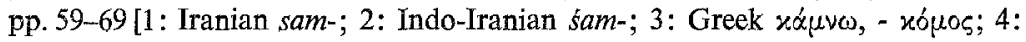
Mesopotamian Aryan; 5: Indian śmaśāná- "tomb"].

Buddhist Remains In India, Edited by Dr. A. C. Sen (New Delhi, 1956), 141 pp. with pls., ill. and maps [Contributors: A. Ghosh, Dr. A. C. Sen, Debala Mitra, Dr. D. R. Patil, Dr. K. K. Ganguli, M. N. Deshpande].

Collinder, Buörn, Zur indo-uralischen Frage, Språkvetenskapliga Sällskapets $i$ Uppsala Förhandlingar, 1952-54, pp. 79-91 [maintains the possibility of a historical connexion between Indo-European and Uralian against Kronasser. p. 85: Skt. ásta- "home" from as- "to be"].

Edgerton, Franklin, On Editing Buddhist Hybrid Sanskrit, JAOS, 77 (1957), pp. $184-192$.

-, Review of Ernst Waldschmidt, Das Mahāvadānasütra. - JAOS, 77 (1957), pp. 227-232.

Indo-Astan Culture, V, No. 3 (New Delhi, 1957), pp. 243-352; VI, No. 1 (New Delhi, 1957), pp. 1-114.

JAHN, KARL, The Yugas of the Indians in Islamic Historiography, Der Islam (1957), pp. $127-134$.

KamtapRasad Guru, Grammatika Xindi, Čast' I, Perevod s xindi P. A. i R. I. Barannikovyx. Izdatel'stvo inostrannoj literatury (Moskva, 1957), 236 pp. [Translation of Hindī Vyäkaran (Kāśī, 1952), with many valuable remarks and additions by the translators].

KrishnamurTI, Bh., Sandhi in modern colloquial Telugu, Ind. Ling., 17 (1957), pp. $178-188$.

KuN CHANG, Review of Ernst Waldschmidt, Das Mahāvadānasütra, II. - Language, 33 (1957), pp. 214-217.

LIEBENTHAL, Walter, The Concept of God in Chinese Religion, Journal of the Asiatic Society, Letters, vol. XXII (Calcutta, 1956), pp. 137-146.

Light of THE DHAMma, IV, 4 (Rangoon, October 1957), $60 \mathrm{pp}$.

Malvania, Paṇpita DalsukhbhaI, Pandita Durveka Miśra's Dharmottarapradipa [Being a sub-commentary on Dharmottara's Nyāyabinduțīā, a commentary on Dharmakīrti's Nyāyabindu], Tibetan Sanskrit Works Series, vol. II (Patna, 1955), vii $+60+303$ pp.

MaSter, Alfred, Some Marathi Inscriptions, A.D. 1060-1300, BSOAS, 20 (1957), pp. 417-435.

MAYRHOFER, MANFRED, ג̇oxóc, Mnemes charin, Gedenkschrift Paul Kretschmer, II (Wien, 1957), pp. 36-39. [Foбxós <* Fapoxos: Skt. vraska-, vrścati].

Mélanges publiés par l'Institut des Hautes Etudes Cunnoises, I, Bibliothèque de l'Institut des Hautes Études Chinoises, Vol. XI (Paris, 1957), vi + 513 pp. [From the contents: G. E. Sargent, "Tchou Hi contre le Bouddhisme" (pp. 1-157); G. Renondeau, "Histoire des moines guerriers du Japon" (pp. 159-345); P. Demiéville, "Le Bouddhisme et la guerre" (pp. 347-385); M. Soymié, "Biographiede Chan Tao-k'ai" (pp. 415-422)]. 
MitteIlungen Des Instituts FüR ORIENTFORsChung, V, 1 (Berlin, 1957), pp. 1-140. MONIER Williams, M., A Dictionary English and Sanskrit (Delhi-Varanasi-Patna, 1956), $\mathrm{xii}+861 \mathrm{pp}$.

RENOU, Lous, Études védiques et pāninéennes, III (Publications de l'Institut de Civilisation indienne, série in $-8^{\circ}$, fascicule 4, Paris, 1957), 135 pp. [1: Les hymnes à l'Aurore du Rgveda (pp. 1-104); 2: Faits de langue propres au Paippaläda-Atharvaveda (pp. 105-119); 3: Études pāninéennes; a) Le Sarasvatīkanțhābharana, b) Kaccāyana et le Kätantra (pp. 121-133)].

RónA TAs, A., Social Terms in the List of Grants of the Tibetan Tun-Huang Chronicle, Acta Orientalia Hungarica, V (Budapest, 1955), pp. 249-270.

Simon, Walter, A Chinese Prayer in Tibetan Script, Festschrift Liebenthal, Sino-Indian Studies, V, Nos. 3-4 (Santiniketan, 1957), 9 pp.

_- Tibetan so and Chinese ya 'tooth', BSOAS, XVIII (1956), pp. 512-513.

—- Tibetan gseb and Cognate Words, BSOAS, XX (1957), pp. 523-532.

--, A Kottish-Tibetan-Chinese Word Equation, Studies Presented to Hu Shih on his Sixty-fifth Birthday, The Bulletin of the Institute of History and Philology Academia Sinica, XXVIII (Taipei, 1956), pp. 441-443.

SirCAR, D. C., Inscriptions of Aśoka (Delhi, 1957), 85 pp., 5 ill., 1 map.

Thieme, PAul, Mitra and Aiyaman, Transactions of the Connecticut Academy of Arts and Sciences, 41 (New Haven, November 1957), pp. 1-96.

_- Vorzarathustrisches bei den Zarathustriern und bei Zarathustra, ZDMG, 107 (1957), pp. 67-104.

\section{CONTRIBUTORS TO THIS ISSUE}

Batley, Harold Walter, born 19 Dec. 1899 Devizes, Wiltshire, England; studied Classics in the University of Western Australia; Sanskrit and Avestan at Oxford University; D. Phil. Oxford with thesis on the Zoroastrian Pahlavī Bundahišn. Lecturer in Iranian Studies, University of London 1929-1936. Professor of Sanskrit, University of Cambridge, from 1936 (for the teaching of Veda, Sanskrit, Historical Grammar, and at first also Iranian). Publications: Zoroastrian Problems in the Ninth Century Books, 1943; Codices Khotanenses, 1938; Khotanese Texts, I-III, 1945-1957; Khotanese Buddhist Texts, 1951; articles from 1929 in periodicals, especially BSOAS, in other journals, and in congratulatory volumes.

JANERT, KLAUS LUDWIG, geb. im J. 1922, studierte Indologie mit Tamil, Slawistik und Indogermanistik in Halle, promovierte zu Göttingen, jetzt dort in der Universitätsbibliothek angestellt. Verfasser von Sinn und Bedeutung des Wortes "dhäsi" und seiner Belegstellen im Rigveda und Awesta, Göttinger Asiatische Forschungen, 7 (Wiesbaden, 1956).

LoKesh ChandRA, born in April 1927; M. A. Lahore, 1947; D. Litt. Utrecht, 1950; joint author of the Comprehensive English-Findi Dictionary of Technical Terms (Nagpur, 1955); working on a Dictionary of Classical Tibetan. Publications: The Jaiminiya Brähmana II, I-80 (Gavāmayana), thesis Utrecht (Nagpur, 1950); Jaiminìya Brähmana of the Sämaveda (Nagpur, 1954); completed and saw through the press Caland's Translation of the Ŝañkhāyana Śrautasūtra with detailed introduction (Nagpur, 1953).

Hensgen, Hans, see p. 83.

KUIPER, F. B. J., see Vol. I, p. 108. 